\title{
Um possível diálogo entre teologia e psicanálise a partir de Jürgen Moltmann e Sigmund Freud
}

\section{A possible dialogue between theology and psychoanalysis from Jürgen Moltmann and sigmund Freud}

Fernando Cardoso Bertoldo*

Resumo: Neste artigo, pretendemos desenvolver um diálogo entre a teologia de Moltmann e a psicanálise de Freud. Assim, trabalhará o conceito de onipotência nas teorias freudianas, dialogando com o conceito da natureza humana de Deus segundo Jürgen Moltmann. Como teoriza Moltmann, é imprescindível conhecer o envolvimento de Deus no sofrimento de Jesus Cristo para compreender a relação entre a maturidade cristã e o sofrimento divino. Isso porque é justamente o sofrimento de Cristo que dá sentido à existência humana. Essa perspectiva, inclusive, cria uma convergência entre a teologia de Moltmann e a psicanálise: se Freud defendia que o ser humano precisa se libertar das ilusões e perceber que está sozinho e desamparado, tal sentimento de abandono constituiria sua maturidade, amparada no sofrimento de Jesus Cristo.

Palavras-chave: Sigmund Freud; Jürgen Moltmann.; Neurose Obsessiva; Maturidade cristã

* Mestre em Teologia pela PUC-RS. Doutorando em Teologia pela EST. Bolsista CAPES. E-mail: nandobertoldo@ hotmail.com. 
Abstract: In this article we intend to develop a dialogue between Freud's theology and psychoanalysis, thus, we will work on the concept of omnipotence in Freudian theories, dialoguing with the concept of human nature of God according to Jürgen Moltmann. As Moltmann theorizes, it is imperative to know the involvement of God in the suffering of Jesus Christ to understand the relationship between Christian maturity and divine suffering. For it is precisely the suffering of Christ that gives meaning to human existence. This perspective also creates a convergence between Moltmann's theology and psychoanalysis: if Freud argued that the human being must free himself from illusions and realize that he is alone and helpless, such a feeling of abandonment would constitute his maturity, supported by the suffering of Jesus Christ.

Keywords: Sigmund Freud; Jürgen Moltmann; Obsessive Neurosis; Christian maturity

\section{Introdução}

Ao longo deste artigo, buscamos desenvolver um diálogo entre a psicanálise de Freud e a teologia de Moltmann. Com base nessa interação, chegaremos a algumas conclusões com relação às suas possibilidades e limites. Ao reconstruirmos a gênese do fenômeno religioso segundo Freud, percebemos que a sua origem judaica se faz notável ao longo de toda sua obra, tanto quanto sua formação científica com resquícios marcantes do Iluminismo. Tal formação parece conduzi-lo a extirpar todo e qualquer vestígio de misticismo de sua análise, assim como tem feito a ciência de um modo geral. A obra de Freud não contempla a possibilidade de que a religião possa contribuir para $\mathrm{o}$ amadurecimento psíquico do ser humano. $\mathrm{O}$ autor parte do pressuposto de que a religião é um fruto de desejos de ordem inconsciente, tais como a neurose obsessiva. À vista disso, a fonte primordial do sentimento religioso, na concepção freudiana, seria o assassinato simbólico do pai primitivo.

Acreditamos que Freud deixou em aberto várias questões sobre o infantilismo religioso e a maneira de se libertar dele. É questionável o quanto Freud conhecia sobre a psique humana saudável, visto que seus pacientes eram 
todos neuróticos - ou, pelo menos, é o que assumimos, presumindo que sua análise sobre seus pacientes estava correta. Em nenhum momento, Freud contemplou a possibilidade da religião apresentar uma visão madura do mundo. Nossa crítica, portanto, busca salientar que, para o autor, a religião é incapaz de contribuir para o amadurecimento dos homens, sendo mero infantilismo psíquico. Questionamo-nos também o porquê da diminuição de religiosos no mundo não implicar, consequentemente, na redução de pacientes neuróticos.

Sob o ponto de vista da teologia de Moltmann, podemos levantar questões sobre as naturezas humana e divina de Deus, questionando até que ponto Deus pode sofrer sem perder sua natureza divina e em que medida ele pode amar a humanidade sem deixar de ser divino. Essa ideia de sofrimento divino proposta por Moltmann quebra o estereótipo da apatia de Deus frente ao sofrimento humano, o que vem tornando esse debate cada vez mais interessante.

Reconhecer o sofrimento divino é, para Moltmann, reconhecer a humanidade de Deus - pré-requisito para uma compreensão madura da religião. Assim, as pessoas que permanecem apegadas a rituais obsessivos, que obedecem a uma religiosidade caricatural são as que não atingiram a maturidade necessária para discernir entre o que é saudável e o que é neurótico, não entendendo Deus em uma perspectiva geral. Logo, abandonar essa religiosidade caricatural, assim como as ilusões e obsessões, é o único caminho possível para que o ser humano encontre a plenitude.

\section{Do delírio da onipotência ao ser humano maduro e livre}

$\mathrm{Na}$ análise de Freud sobre o caráter patológico do fenômeno religioso, a questão da onipotência tem um papel central. No texto Notas sobre um caso de neurose obsessiva, de 1909, Freud afirma:

$\mathrm{Na}$ fase animista, os homens atribuem a onipotência a si mesmos. Na fase religiosa, transferem-na para os deuses, mas eles próprios não desistem dela totalmente, porque se reservam o poder de influenciar os deuses 
através de uma variedade de maneiras, de acordo com os seus desejos. A visão científica do universo já não dá lugar à onipotência humana; os homens reconheceram a sua pequenez e submeteram-se resignadamente à morte e às outras necessidades da natureza. Não obstante, um pouco da crença primitiva na onipotência ainda sobrevive na fé dos homens no poder da mente humana, que entra em luta com as leis da realidade. ${ }^{1}$

Claramente, Freud não exclui a própria ciência de seu escrutínio. O autor chama a atenção para o fato de que todo ser humano é falível e que até mesmo a confiança no racionalismo pode apresentar resquícios de uma fé neurótica e um desejo irrealista por onipotência.

De qualquer forma, o posicionamento de Freud é inegavelmente ateu, o que leva Moltmann a criticá-lo em $O$ Deus crucificado, atribuindo-lhe o que chamou de "ateísmo de protesto":

O ateísmo de protesto, no entanto, se equivoca ao divinizar o homem no lugar de Deus, a fim de declará-lo o ser mais elevado para o homem como enquanto onipotente, justo, infinito e bom. $\mathrm{O}$ ateísmo de protesto se equivoca quando apresenta o gênero humano, à sociedade humana ou a sua vanguarda, um partido humanista, com predicados divinos herdados do teísmo; ou seja, que ele é imortal, sempre tem razão, que oferece segurança, autoridade, etc. Esse ateísmo só chega então a sua própria verdade quando reconhece o homem enganado, amante e sofredor, injusto e indignado contra a injustiça, e impotente em sua humanidade entende que, nessas suas experiências humanas, ele é maior que todos os deuses, divindades e ídolos. ${ }^{2}$

O ateísmo identificado por Moltmann, sob o rótulo de "ateísmo de protesto", simplesmente não pode ser um ateísmo verdadeiro, visto que, para ele, o ateu de protesto divinizaria o ser humano e se consideraria acima dos

1 FREUD, S. Duas histórias clínicas (o pequeno Hans e o homem dos ratos). Rio de Janeiro: Imago, 1996. p. 98-99.

2 MOLTMANN, J. O Deus crucificado: a cruz de Cristo como base e crítica da teologia cristã. Santo André (SP): Academia Cristã, 2011, p. 277-278. 
deuses e ídolos. Ora, qualquer indivíduo que acredite na divinização humana ou na superioridade humana sobre deuses necessariamente não é um ateu, uma vez que atribui o status de realidade ao divino. Caberia ainda nos perguntarmos o motivo pelo qual Moltmann atribui a Freud o rótulo de "ateu de protesto", já que a psicanálise, como vimos, busca ser neutra, como toda ciência.

Com relação ao desejo de potência, Freud argumenta que é durante a infância que o ser humano primeiramente identifica-se com a onipotência. Para ele, isso seria revelado pelo desejo infantil por regalias e pela obtenção de todos os direitos, assim como por exclusividade de tratamento e pela exclusão de tudo o que não está de acordo com os parâmetros de seus anseios. Para Freud, a luta psicológica do ser humano adulto pode ser resumida pela busca edipiana pela onipotência, assim como pela tentativa de suprimir o medo de perdê-la. Tratase, portanto, de uma luta psicológica para se tornar simbolicamente um deus, senhor e pai de si mesmo. A manutenção da onipotência, dessa forma, seria uma atitude narcisista. ${ }^{3}$ Acerca dessas teses, Freud esclarece:

\begin{abstract}
Estou-me referindo à onipotência que ele atribuía aos seus pensamentos e sentimentos, e aos seus desejos, quer os bons quer os maus. Devo admitir ser decididamente tentador declarar que essa ideia era um delírio e que ela ultrapassa os limites da neurose obsessiva. Não obstante, tenho deparado com essa mesma convicção em outro paciente obsessivo; e há muito tempo que recuperou a saúde e vive uma vida normal. De fato, todos os neuróticos obsessivos comportam-se como se compartilhassem dessa convicção. Será nossa incumbência esclarecer, de algum modo, a superestimação com que os pacientes revestem as suas forças. Admitindo, sem mais delongas, que essa crença seja um reconhecimento sincero de uma lembrança da antiga megalomania da tenra infância, prosseguiremos indagando nosso paciente acerca dos fundamentos de sua convicção. ${ }^{4}$
\end{abstract}

\footnotetext{
3 Cf. MORANO, C. D. Crer depois de Freud. Tradução de Eduardo Dias Gontijo. São Paulo: Loyola, 2009, p. 409.

4 FREUD, S. Duas histórias clínicas (o pequeno Hans e o homem dos ratos). Rio de Janeiro: Imago, 1996. p. 202-203.
} 
Moltmann entende que o delírio da onipotência pode ser superado pelo ser humano adulto e que a racionalidade crítica defendida por Freud é, de fato, necessária para que os indivíduos possam aceitar a religião de um modo saudável.

Libertar o homem doente dos seus círculos viciosos oferece não somente a racionalidade crítica e suporte ao ego que são geralmente invocadas contra as estratégias psicológicas do mal, mas também oferece a nova vivacidade espontânea que é necessária a racionalidade crítica, como atmosfera na qual se pode desenvolver livremente. ${ }^{5}$

Alfonso Rubio também concorda, em grande parte, com Freud no que tange à tendência humana ao infantilismo e à busca por amparo psicológico por meio de crenças delirantes. Sua análise volta-se para as problemáticas da religiosidade cristã:

É fácil perceber que a experiência religiosa cristã não está livre da suspeita de ilusão e autoengano. Igualmente, não está livre da projeção em Deus do desejo de onipotência que leva consigo uma perturbadora, conflituosa ambivalente experiência: amparo, apoio, segurança, por um lado, e medo, revolta e sentimento de culpa, por outro. Não é novidade a constatação de quanto está espalhado, em nossas comunidades eclesiais, um certo tipo de infantilismo religioso, que se situa no polo oposto da atitude de fé adulta proposta pela revelação bíblica. Como poderá viver uma fé amadurecida a pessoa que está prisioneira de um psiquismo imaturo, de infantilismo, das ilusões e da mentira - normalmente inconscientes? Como poderá viver essa fé a pessoa que não superou adequadamente a problemática edipiana com os sentimentos de culpa que a acompanham? [...] Será que a religião é um campo privilegiado para a fuga e a alienação da realidade? ${ }^{6}$

\footnotetext{
5 MOLTMANN, O Deus crucificado, p. 386.

6 RUBIO, A. G. A fé cristã em Deus Pai e a crítica freudiana da religião. Atualidades Teológicas, Rio de Janeiro, ano VII, n. 15, p. 296-322, 2003, p. 312-313.
} 
A preocupação de Rubio é inteiramente legítima, haja vista a grande influência que o infantilismo psicológico ainda provoca na vida das pessoas, assim como sua ampla ocorrência em todas as sociedades. $\mathrm{O}$ fenômeno da imaturidade e do apelo às ilusões causa problemas em diversas áreas, e não seria diferente no âmbito religioso.

Anteriormente, havíamos questionado sobre a razão pela qual a diminuição da religiosidade no mundo não acarretou, como consequência, a redução das ocorrências de neurose. O próprio Freud, no entanto, parece ter respondido a essa questão:

O desamparo do homem [sem religião], porém, permanece e, junto com ele, seu anseio pelo pai e pelos deuses. Estes mantêm sua tríplice missão: exorcizar os terrores da natureza, reconciliar os homens com a crueldade do Destino, particularmente a que é demonstrada na morte, e compensá-los pelos sofrimentos e privações que uma vida civilizada em comum lhes impôs. ${ }^{7}$

Para Freud, portanto, os anseios que levam o ser humano à religião não podem ser inteiramente superados, pois são independentes da religiosidade e fazem parte da própria experiência de vida humana. Ele identificou esses anseios como: ter a natureza e o mundo sob controle, obtendo conforto; controlar a interpretação do mundo sob alguma lógica, reduzindo os efeitos da imprevisibilidade do destino; escapar da morte.

Moltmann questiona essa perspectiva de desamparo humano, defendendo que a vivência da fé e da religião apenas cumpriria um papel estabilizador do indivíduo em suas relações inumanas, "pelo fato de criar para a interioridade humana o ambiente que, fora, ela não encontra". ${ }^{8}$ Entretanto, a principal crítica de Moltmann é a de que, como já vimos, o desamparo e abandono vivenciado pelos homens também seria vivenciado por Deus.

7 FREUD, S. O mal-estar na civilização (1929/1930). Rio de Janeiro: Imago, 1996, p. 26.

8 MOLTMANN, J. Teologia da esperança: estudos sobre os fundamentos e as consequências de uma escatologia cristã. São Paulo: Loyola, 2005, p. 378. 
Acreditamos, também, que Freud restringiu sua análise da realidade a aspectos psicológicos, deixando de perceber outros aspectos importantes. Concordamos com Antoine Vergote: "tudo que é humano e, portanto, o sentido de Deus e do pecado, tem uma dimensão psicológica. Mas nada do que é humano é exclusivamente psicológico"".

Em Totem e tabu, Freud trabalha detalhadamente a relação entre o complexo de Édipo e a luta pela onipotência, atribuindo ao sentimento de culpa do parricídio a razão pela qual os indivíduos, na busca pela reparação de sua falta moral, procuram fazer justiça ao pai primitivo por meio da experiência religiosa. Em suma, como já vimos, o ser humano enxergaria em Deus a figura paterna, por meio de uma projeção psicológica de papéis.

Morano, identificando nos casos concretos do cristianismo e do judaísmo essa tese freudiana, afirma:

O cristianismo - com sua doutrina do pecado original - manifestaria efetivamente, melhor que qualquer outro sistema religioso, esse acontecimento primordial da morte do pai. Tornando necessária a morte do filho, levaria a cabo, na ordem da fantasia dogmática, a expiação da culpa original pela morte do pai. A eterna ambivalência que sela, porém, toda forma de expressão religiosa faz com que o pai renasça das cinzas e se imponha novamente, promovendo o dogma cristão da ressurreição e divinização do filho morto, o qual vem desse modo a suplantar mais uma vez o pai. O judaísmo, contudo - que assistiu ao renascimento do pai primitivo da horda no Deus único Aton, importado por Moisés do Egito não soube reconhecer que havia assassinado o pai. O preço dessa negativa foi pago, em parte, pela sua redução à categoria de fóssil religioso, e, por outra, pela perseguição de que foi objeto ao longo de toda a sua história. ${ }^{10}$

9 VERGOTE, A. Processos psicológicos - vergonha, sentimento de culpa - e sentido bíblico do pecado, em particular em Romanos 7. São Paulo: Loyola, 2001, p. 128.

${ }^{10}$ MORANO, Crer depois de Freud, p. 39-40. 
Essa tese da projeção paterna, porém, é parcialmente negada por Moltmann. Para o teólogo, o fenômeno da projeção descrito por Freud é real, mas só se aplicaria aos casos patológicos. Nos casos identificados por Moltmann como experiências religiosas maduras, a imagem divina do pai seria uma outra entidade inteiramente diferente:

Não é o mesmo pai em dois lugares. O pai desconhecido de Jesus Cristo não tem nada a ver com aqueles ídolos do pai que levam ao complexo de Édipo. O Cristo crucificado faz com que os pais e filhos terrenos sejam como filhos de Deus, e os leva a uma comunhão com liberdade que se encontra além do complexo de Édipo. Originalmente, o cristianismo não é uma religião paternal; se é de fato uma religião, seria uma religião filial, a saber, uma comunhão fraternal na situação do Deus humano, sem privilégios e sem as rebeliões necessárias contra esses privilégios. O parricida e o blasfemo estão expostos à aniquilação e, portanto, caem na apatia. Ele se rebela contra as restrições colocadas pela autoridade do pai, mas a sua rebelião não o livra de ser uma imagem espelhada do seu adversário. No conflito de Édipo, ele continua preso ao seu oponente. Para a fé cristã, o Crucificado se coloca entre Deus executado e os seus apáticos e insensíveis executores. O conflito entre culpa e ansiedade, entre uma libertação culpada e a reconciliação necessária, entre autoridade e aniquilação, é transferido para o próprio Deus. Deus se permite ser humilhado e crucificado no Filho, a fim de libertar os opressores e os oprimidos da opressão e para abrir-lhes a situação da humanidade livre e compassiva. ${ }^{11}$

Notamos, assim, que as posições de Moltmann e Morano são contrárias no que tange à natureza paternal do cristianismo. Discordamos de Morano, acreditando que a religião cristã é de natureza filial, como defende Moltmann. De acordo com o teólogo, Deus não possuiria qualquer privilégio sobre sua criação. Concordamos com Moltmann, para quem

[...] a presunção do ateísmo metodológico é prematura e infundada. Pode se concordar prontamente com o veredicto das ciências sociais de que a

\footnotetext{
${ }^{11}$ MOLTMANN, O Deus crucificado, p. 377.
} 
religião é um fenômeno humano; com efeito, seria estupidez negá-lo. Contudo, está longe de ser óbvio que também seria estupidez negar que ela é simplesmente uma instituição humana; que não possui nenhuma origem ou causa (ou sentido, referência) transcendente e, portanto, numinosa. ${ }^{12}$

Em outras palavras, Moltmann afirma que os críticos da religião precisam considerar o aspecto transcendente da fé. Na citação acima, porém, o autor estabelece uma falsa equivalência entre "origem ou causa" e "sentido, referência", não deixando claro seu posicionamento. As ciências sociais já levam em consideração tanto a crença em aspectos transcendentes, como também seu sentido para os religiosos e as referências simbólicas das religiões. Porém, uma ciência que tomasse por verdade a origem ou a causa do cristianismo segundo a fé dos cristãos acabaria deixando de ser ciência e perderia sua neutralidade.

Apesar desses conflitos entre a teologia de Moltmann e o entendimento das atribuições da ciência, acreditamos que sua crítica é válida ao estabelecer que a passibilidade divina só pode ser contemplada quando renunciamos à nossa onipotência e nos libertamos das distorções religiosas. Moltmann acredita que, para além da ilusão, existe um Deus que tem compaixão pelo sofrimento humano, e argumenta que:

Se ele [Deus] tem a capacidade de amar a outro, então se abre ao sofrimento que lhe é proporcionado pelo amor desse outro, e coloca-se acima da dor que daí nasce em virtude do seu amor. Deus não sofre como sofre a criatura, por carência de ser. Nesse sentido, sim, ele é impassível. Mas sofre em seu amor (caritas est passio), que outra coisa não é senão a superabundância do seu ser. Nesse sentido, ele é passível. ${ }^{13}$

12 WIEBE, D. Religião e verdade: rumo a um paradigma alternativo para o estudo da religião. São Leopoldo: Sinodal, 1998, p. 118.

13 MOLTMANN, J. Trindade e Reino de Deus: uma contribuição para a teologia. Petrópolis: Vozes, 2000, p. 37. 
Morano questiona esse posicionamento da passibilidade divina, uma vez que, segundo sua crítica da religião, acredita que tomar o lugar do pai é a grande expressão da onipotência sonhada pelo ser humano. Na existência de Deus, assim como na existência desejada pela humanidade, não haveria restrições, mas a possibilidade da livre realização de todos os desejos. ${ }^{14}$

Porém, discordamos da opinião de Morano, uma vez que:

O lugar vivencial do predicado da onipotência era, portanto, de modo direto ou indireto, o diálogo entre Deus e o ser humano. O Credo leva isso em conta quando, primeiramente, confessa a Deus como Pai, e só depois como o TodoPoderoso. Com isso, o Todo-Poderoso é definido como aquele que se identificou, ele próprio, em seu filho, identificou-se como nosso Pai, é, como um "tu" voltado misericordiosamente para nós. Em termos conceituais: o discurso acerca do "Todo-Poderoso" se torna equivocado sempre quando se o isola da relação com Deus. Então a ideia se transforma na noção de Deus como tirano (com o qual então gostam de se legitimar tiranias terrenas). ${ }^{15}$

Assim, entendemos que a revelação de Deus em Cristo é, fundamentalmente, a renúncia de ídolos e de poder. Consequentemente, Deus nos ampararia ao abandonar-se em nosso sofrimento por amor à humanidade. Portanto, a perspectiva de Moltmann constitui uma severa crítica à perspectiva freudiana da religião, tendo em vista que é a compreensão humanizada de Deus que nos humaniza. A única onipotência em Deus é, desta forma, a onipotência do seu amor padecente, revelado radicalmente na cruz de Cristo. ${ }^{16}$

\section{O Pai de Jesus Cristo contraria a experiência religiosa como neurose obsessiva}

${ }^{14}$ Cf. MORANO, C. D. El psicoanálisis freudiano de la religión: análise textual y comentário crítico. Madrid: Paulinas, 1990, p. 413.

${ }^{15}$ FELDMEIER, R. Nem supremacia nem impotência. A origem bíblica da confissão da onipotência de Deus. Estudos Teológicos, São Leopoldo, ano 37, n. 2, p. 109-128, 1997, p. 122.

${ }^{16}$ Cf. KITAMORI, K. Teologia del dolor de dios. Salamanca: Sigueme, 1975, p. 199-206. 
Segundo Freud, como vimos, o fenômeno da religião tem um papel central na contenção social de patologias individuais de ordem neurótica. A civilização, para Freud, constrói-se com base na onipotência enquanto projeção de deuses e ídolos, ilusões utilizadas com a finalidade da sociedade não sucumbir. Ainda segundo Freud,

nossa civilização repousa, falando de modo geral, sobre a supressão dos instintos. Cada indivíduo renuncia a uma parte dos seus atributos: a uma parcela do seu sentimento de onipotência ou ainda das inclinações vingativas ou agressivas de sua personalidade. Dessas contribuições resulta o acervo cultural comum de bens materiais e ideais. Além das exigências da vida, foram sem dúvida os sentimentos familiares derivados do erotismo que levaram o homem a fazer essa renúncia, que tem progressivamente aumentado com a evolução da civilização. Cada nova conquista foi sancionada pela religião, cada renúncia do indivíduo à satisfação instintual foi oferecida à divindade como um sacrifício, e foi declarado 'santo' o proveito assim obtido pela comunidade. ${ }^{17}$

Contrariamente a isso, acreditamos que a religião não tem a função de conter os instintos e permitir o avanço e o desenvolvimento da civilização, mas, sim, contribuir para a libertação das ilusões e distorções causadas pelo desejo de onipotência. Diante disso, concordamos com Moltmann, para quem

O Deus crucificado renuncia a esses privilégios de ídolos. Ele quebra o encanto do superego, o qual os homens colocam sobre ele, pois precisam dessa autoproteção. Ao humilhar-se e tornar-se carne, ele não aceita as leis desse mundo, mas toma o sofrimento, o homem ansioso em sua situação. Ao tornar-se fraco, impotente, vulnerável e imortal, ele liberta o homem da busca pelos ídolos poderosos e das compulsões protetoras, preparando-o para aceitar sua humanidade, sua liberdade e sua mortalidade. ${ }^{18}$

${ }^{17}$ FREUD, S. Moral sexual "civilizada" e doença nervosa moderna (1908). "Gradiva" de Jensen e outros trabalhos (1906-1908). Rio de Janeiro: Imago, 1976, p. 173.

${ }^{18}$ MOLTMANN, O Deus crucificado, p. 371. 
Dessa forma, a passividade divina diante do sofrimento humano não representa a apatia com relação à humanidade, retratada por um Deus apático e insensível que, segundo Freud, existe enquanto ilusão que controla os instintos. Ao revés, trata-se do abandono de Deus no sofrimento dos homens, contradizendo a perspectiva neurotizada da religião. Portanto, a psicanálise pode e deve se tornar uma aliada no processo de amadurecimento psíquico, tendo em vista que a experiência cristã madura passa necessariamente pela libertação psíquica dos homens, ou seja, faz-se necessário que consigamos nos libertar das projeções infantis para entendermos o significado de ser cristão.

Por outra via, segundo Morano, a questão do Édipo está sempre presente enquanto atualizadora da crise de amor e ódio com relação ao deuspai, que contempla todos os sentimentos de ambivalência, como amor e ódio, entre outras formas de sentimentos calcados na deificação dos homens. Segundo Reinhard Feldmeier, "em face do sofrimento injusto impune existente no mundo, Deus não poderia ser concebido ao mesmo tempo como bondoso e poderoso, razão por que se deveria renunciar à ideia de onipotência"19. Isso demonstra que Deus não é necessariamente onipotente, mas que também tem uma natureza humana e que não se restringe a ser um Deus perverso e onipotente diante do sofrimento humano. Contudo, segundo Freud, a questão do assassinato do pai primitivo enquanto origem da religião vem a questionar a natureza humana de Deus, buscando demonstrar que:

Não pode haver dúvida de que no mito cristão o pecado original foi um pecado cometido contra o Deus-Pai. Se, entretanto, Cristo redimiu a humanidade do peso do pecado original pelo sacrifício da própria vida, somos levados a concluir que o pecado foi um homicídio. A lei do Talião, que se acha tão profundamente enraizada nos sentimentos humanos, estabelece que um homicídio só pode ser expiado pelo sacrifício de outra vida: o autossacrifício aponta para a culpa sanguínea. E se este sacrifício

\footnotetext{
${ }^{19}$ FELDMEIER, Nem supremacia nem impotência, p. 110.
} 
de uma vida ocasionou uma expiação para com o Deus-Pai, o crime a ser expiado só pode ter sido o homicídio do Pai. ${ }^{20}$

Em Totem e tabu, tanto a religião como a obsessão neurótica estão sempre rememorando vivências de ordem primitiva. Para Morano, é "uma luta que, [...] de maneira bem paradoxal, não deixa de revelar o desejo paralelo do filho de viver sempre sob o amparo e a proteção paterna"21.

Essa questão abre precedentes para questionamentos, tendo em vista que, de acordo com a perspectiva teológica de Brakemeier, "Deus, antes de ser juiz, é pai amoroso, a quem o ser humano pode dirigir-se sem medo e com toda a confiança, como filhos amados ao querido pai”,22. Jesus, ao longo de sua trajetória, demostrou que Deus agia por compaixão com a humanidade, uma vez que isso era uma reação ao sofrimento humano, algo mostrado na realidade da esperança apocalíptica.

A escatologia é o tema central da teologia e, não, um apêndice. Isso nos permite perceber a compaixão de Deus com o sofrimento humano. A virtude cristã passa a ser internalizada, segundo nossa perspectiva, quando compreendemos a face humana de Deus, libertando-nos das distorções relacionadas à religião, como também de seu aspecto neurotizado. Acreditamos que essas virtudes nos permitem entender a promessa apocalíptica relatada por Jesus Cristo. A promessa está no centro da teologia. Então, a libertação psíquica permite uma real compreensão da promessa apocalíptica, na qual compreendemos a entrega de Deus diante do sofrimento da criação. Freud discorda, ressaltando que:

Para começar, sabemos que Deus é um substituto paterno, ou, mais corretamente, que ele é um pai exaltado, [...]. Posteriormente na vida, o indivíduo vê seu pai como algo diferente e menor. Porém, a imagem ideativa

\footnotetext{
${ }^{20}$ FREUD, S. Totem e tabu (1913[1912-13]). Rio de Janeiro: Imago, 1996, p. 156.

${ }^{21}$ MORANO, Crer depois de Freud, p. 41.

${ }^{22}$ BRAKEMEIER, G. O ser humano em busca de identidade: contribuições para uma antropologia teológica. São Leopoldo: Sinodal; São Paulo: Paulus, 2002, p. 26.
} 
que pertence à infância é preservada e se funde com os traços da memória herdados do pai primevo para formar a ideia que o indivíduo tem de Deus. ${ }^{23}$

Moltmann acredita que a verdadeira religião mostra que a experiência de maturidade cristã é transpassada por uma libertação psíquica que nos garante o livre-arbítrio e, consequentemente, nos permite entrar em harmonia com Deus no mundo de hoje. Consequentemente, nos permite encontrar, na fé em Cristo, as respostas para a crise de sentido da religião e da fé cristã. Assim,

\begin{abstract}
Nas experiências do Espírito, apercebemo-nos de um relacionamento mais íntimo que o Criador e criatura, e também que o de pai ou mãe com o filho. É a comunhão íntima de um habitar recíproco: Deus de modo divino em nós, e nós de modo humano nele (Jó 4: 116). Na comunhão do Espírito Santo, o eterno Deus participa de nossa vida mortal, enferma e deficiente, e nós participamos da eterna vida de Deus. ${ }^{24}$
\end{abstract}

\title{
Segundo Morano,
}

Deve-se levar em conta, com efeito, que o Deus que se origina da imagem do pai na situação edipiana está impregnado, como esse mesmo pai, da dupla polaridade amor-ódio da ambivalência. Tal ambivalência, contudo, não é visível no engrandecimento ilimitado do pai que ocorreu na figura do Deus monoteísta. O pai amado e odiado se transformou, pois, em um pai que recolhe em si apenas a vertente positiva da ambivalência afetiva. Algo deve ter acontecido no percurso do processo para eliminar a parte perigosa e inquietante da relação. Apenas de modo latente, subterrâneo e por meio de atuações deslocadas de seu lugar originário, essa parte má encontrará vias de possibilidades de dar seu testemunho. Em seus conteúdos manifestos, vem à luz apenas uma imagem boa do pai convertido em um

${ }^{23}$ FREUD, S. Além do princípio do prazer, psicologia de grupo e outros trabalhos (1920-1922). Rio de Janeiro: Imago, 1996, p. 101-102.

${ }^{24}$ MOLTMANN, J. A fonte da vida: o Espírito Santo e a teologia da vida. São Paulo: Loyola, 2002, p. 75. 
Deus providente, sábio e poderoso. Nada, portanto, do pai temido e perigoso da fantasmática edipiana infantil. ${ }^{25}$

Questionamos Morano, destacando que a passibilidade divina demonstra que a existência de sentido na fé cristã é transpassada, atualmente, por um retorno à origem da religião e da fé. Do contrário, ficaremos presos em amarras e ilusões que não podem ser desfeitas enquanto não assumirmos Deus como centro de nossa existência. Portanto, esse diálogo teológico-psicanalítico nos mostra que, quando repensarmos nossas relações parentais, como também nossa relação com Deus, isso nos permitirá perceber que, por meio do livrearbítrio, somos capazes de compreender, na passibilidade divina, o sentido da existência cristã. Quando nos libertamos psiquicamente, amadurecemos psiquicamente, e isso também nos permite amadurecer como cristãos.

Segundo Freud, a religião se caracteriza pela necessidade do retorno à origem, pela necessidade de retorno do conforto gerado pelo seio materno. "Há, porventura, algo mais natural do que persistirmos na busca da felicidade do modo como a encontramos pela primeira vez?"26

Discordamos desse posicionamento de Freud, tendo em vista que, segundo Moltmann, Deus não se caracteriza por ser uma válvula de escape para o desamparo humano, no qual Deus não passaria de uma forma criada pelos seres humanos para suportar a crise de sentido existencial e a solidão diante da finitude humana. Deus "não é um 'poder celestial frio', nem 'trilha o seu caminho sobre cadáveres', mas é conhecido como o Deus humano no Filho do Homem crucificado"27. Então, "se Deus é amor, então ele não apenas prodigaliza o amor, mas também espera o amor e dele necessita: o seu mundo deve ser o seu lar. Nele ele deseja morar" 28 . Morano questiona essa perspectiva:

\footnotetext{
${ }^{25}$ MORANO, Crer depois de Freud, p. 57-58.

${ }^{26}$ FREUD, S. O mal-estar na civilização (1929/1930). Rio de Janeiro: Imago, 1996, p. 89.

${ }^{27}$ MOLTMANN, O Deus crucificado, p. 284.

${ }^{28}$ MOLTMANN, Trindade e Reino de Deus, p. 111.
} 
Essa ilusão parte da crença segundo a qual o líder, Jesus, no caso da igreja, ama com amor de irmão mais velho (de pai) igualmente a todos os que creem para, depois, todos virem a se converter em irmãos. A ilusão da família harmoniosa está, assim, sustentada pela fé. Cristo, além disso, não se constitui apenas num objeto de amor para todos os que creem, mas, na culminância da ilusão amorosa, propõe-se também como modelo de identificação a partir do qual cada um que crê deve aspirar a oferecer um amor total como o seu. Essa ilusão amorosa, não religiosa em si mesma, mas sustentada pela posição do credo cristão, traz consigo repercussão de grande envergadura. De fato, uma primeira consequência que deriva desse tipo de ilusão é o que o amor, ao ignorar com má-fé as dimensões conflitantes da realidade pessoal, desencadeia justamente aquilo que preferiria ignorar: a agressividade, a intolerância e a exclusão de todos aqueles que ficam à margem do circulo ilusório. Por isso, diz Freud, toda religião é uma religião de amor a seus fieis, ao passo que de crueldade e intolerância para com aqueles que não a reconhecem. A ilusão amorosa que se aninha no seu seio da posição da crença - afirma em outro lugar - pode até mesmo, em alguns casos, chegar a converter-se em mero pretexto para justificar intenções destrutivas. ${ }^{29}$

Nossa crítica parte do pressuposto de que Cristo é Deus e homem. Demonstrada sua humanidade e, portanto, por sua manifestação em nossas vidas, percebemos que Deus se manifesta em nosso sofrimento, não sendo uma figura apática e insensível ao sofrimento. Segundo Ênio Mueller,

Na pessoa de Jesus Cristo temos um duplo aspecto, como a teologia cristã tem reconhecido desde sempre e o belo hino de Fp 2. 5-11 expressa de forma inigualável. Sendo Deus, Jesus esvaziou-se assumindo forma humana e assumindo em si mesmo a condição humana de pecado, até as últimas consequências, a morte na cruz. Temos assim, em Jesus Cristo, o próprio Deus assumindo sobre Si o drama humano: sofrendo os efeitos do pecado até a morte, e ressuscitando ou sendo ressuscitado depois para a vida eterna. ${ }^{30}$

\footnotetext{
29 MORANO, Crer depois de Freud, p. 60-61.

${ }^{30}$ MUELLER, E. R. "Espelho, espelho meu...": reflexões sobre os fundamentos de uma espiritualidade evangélica. Estudos Teológicos, São Leopoldo, ano 37, n. 1, p. 5-27, 1997, p. 8.
} 
Portanto, a imagem do pai que Jesus demonstra está livre de toda e qualquer distorção causada pela neurose obsessiva, como Freud procurou demonstrar ao longo de sua obra. De acordo com Freud, todo ser humano "[...] é capaz de renunciar ao consolo que supõe o fenômeno religioso, e sabe tolerar a angústia proveniente de sua renúncia a esses desejos de eternidade, de plenitude humana, de relação com um Ser superior e pessoal"31.

Nós discordamos disso, tendo em vista que a experiência religiosa em sua forma madura não é capaz de encontrar sustentação enquanto projeções infantis, uma vez que se trata de uma perspectiva mais profunda do que simplesmente a relação de ligação com a mãe. Em contraponto a isso, a experiência mística religiosa dificilmente ocorreria ou amadureceria se, na infância, a pessoa não tivesse experimentado felicidade na fusão primitiva com a mãe. De acordo com Rubio, o conjunto de dificuldades vividas na infância trata-se

[...] apenas de uma primeira experiência, que deverá ser superada por um outro estágio, representado pelo aparecimento da lei (figura do pai), que comporta a limitação do desejo onipotente e ilimitado. Os dois estágios aparecem, assim, necessários como alicerce de uma genuína experiência de Deus. ${ }^{32}$

\section{O Deus crucificado não é totem nem tabu}

Segundo Freud, diante das situações que causam sofrimento e frustação, o ser humano anseia por um deus-pai que cuida e protege. ${ }^{33}$ Entretanto, acreditamos que, na medida em que o ser humano amadurece e consegue superar as conflituosas relações de ordem edipiana, indo ao encontro da maturidade psicológica, ele supera o desejo por onipotência e se encontra em sua própria finitude, tornando possível a sua reconciliação com Deus.

\footnotetext{
31 DROGUETT, J. G. Desejo de Deus: diálogo entre a psicanálise e a fé. Petrópolis: Editora Vozes, 2000, p. 88.

32 RUBIO, A fé cristã em Deus Pai, p. 314.

33 Cf. FREUD, S. O futuro de uma ilusão (1927). Rio de Janeiro: Imago, 1996, p. 26.
} 
Consequentemente, demonstra que Jesus Cristo serve como uma resposta teológica às críticas freudianas.

Jesus é entendido, simultaneamente, como o Deus que se esvazia de poder, que assume o caminho da cruz no mais profundo desamparo e também como o homem que retrata a autêntica humanidade, em um desamparo amparado. Concordamos com Moltmann ao assumir que a ressurreição não esvazia a cruz, mas a preenche de significado. A partir dessa perspectiva, percebemos que a relação com o pai não é mais marcada pela onipotência, mas pela entrega e solidariedade no abandono, ou seja, a relação não é mais marcada pela disputa da onipotência, não é mais medida e orientada pelo narcisismo e pela privação, enquanto renúncia de instintos, exigida pelo Deus da ilusão, com vista a uma retribuição enquanto justiça final, mas pela analogia.

Morano discorda. Segundo o autor,

Como o pai da infância, que vigiou e protegeu a criança débil e indefesa dos perigos do mundo exterior, o Deus da ilusão proporciona também toda a segurança de que o adulto necessita para subsistir num mundo frequentemente hostil. Assim como o pai da infância, que segundo a mentalidade mágica infantil sabe tudo e conhece tudo, também o Deus da ilusão possuirá o atributo da onisciência. E desse saber ilimitado o adulto também obterá uma explicação formidável de todos os mistérios e incógnitas que a vida lhe apresenta. Finalmente, o Deus ilusório, de acordo com o modelo do pai educador, apresenta-se também como garantia de uma justiça final e como retribuidor, através do dom da imortalidade, de todas as renuncias e todos os sacrifícios que tão penosamente o homem deve suportar no curso de sua existência terrena. ${ }^{34}$

Contrariamente ao posicionamento de Morano, concordamos com Tillich, quando afirma que:

O Cristo pré-existente abandona a sua forma divina, torna-se um servo, e experimenta a morte de um escravo. Pré-existência e autoentrega são

${ }^{34}$ MORANO, Crer depois de Freud, p. 65-66. 
combinadas nesse simbolismo. Ele corrobora o símbolo central da cruz, [...]. A mesma ideia é expressa [...] nas histórias do nascimento de Cristo em Belém, de seu estar reclinado numa manjedoura, de sua fuga ao Egito e da ameaça à sua vida, já logo nos primórdios, causada pelos poderes políticos. [...]. Na cena do "Getsêmani”, de sua morte e sepultamento, tudo isso chega a um clímax. Todos esses traços, que poderiam ser multiplicados e elaborados, são resumidos no símbolo da cruz. ${ }^{35}$

Partimos do pressuposto de que Freud acreditava que a consequência disso seria o surgimento da religião e, quando a humanidade conseguisse renunciar aos ídolos, seria o fim da religiosidade. Todavia, discordamos dessa tese de Freud, tendo em vista que a experiência religiosa madura envolve nos darmos conta de nossa humanidade, falibilidade, fragilidade e singularidade. Isso só é possível quando aceitamos nossa humanidade. Ou seja, a percepção de Freud de que a humanização seria o fỉm da religião, de certa forma, está errada, uma vez que, segundo nossa pesquisa, vem a ser justamente em nossa humanidade que compreendemos o sofrimento de Deus, como também sua entrega e abandono em nosso sofrimento, o que se contrapõe à ideia de autodivinação, tornando possível que nos libertemos psiquicamente das enfermidades de ordem emocional, para seguirmos no caminho de Cristo. Portanto, a figura do crucificado é paradigmática, pois, da meditação da cruz (meditatio crucis), emerge o sentido do seguimento. ${ }^{36}$

Freud critica essa perspectiva, pois, segundo ele, a religião seria fruto de um desejo bem determinado, de permanecer vivo, defendendo-se das forças agressoras. Seria apenas um desejo ligado às necessidades humanas. Portanto, a religião seria um fenômeno criado pelos seres humanos.

[...] são ilusões, realizações dos mais antigos, fortes e prementes desejos da humanidade. O segredo de sua força reside na força desses desejos. Como já sabemos, a impressão terrificante de desamparo na infância despertou a

35 TILLICH, P. Teologia sistemática. Tradução de Getúlio Bertelli. São Leopoldo: Sinodal, 2002, p. 366.

36 MOLTMANN, Trindade e Reino de Deus,, p. 23. 
necessidade de proteção - de proteção através do amor -, a qual foi proporcionada pelo pai; o reconhecimento de que esse desamparo perdura através da vida tornou necessário aferrar-se à existência de um pai, dessa vez, porém, um pai mais poderoso. ${ }^{37}$

Moltmann questiona isso ao afirmar que, ao se adornar dos predicados divinos, o ateísmo atribui ao próprio humano os atributos de onipotência e bondade herdados da concepção teísta de Deus. A postura moltmanniana é a de que, em vez de tornar o ser humano um humano, a sua autodivinização o conduz a uma desumanização. ${ }^{38}$

Por outra via, quando Freud elenca os fatores da gênese do religioso, ele os concentra nos anseios e necessidades pessoais universais. Em outras palavras, a religião foi criada pelo ser humano para que atendesse a suas necessidades de proteção. No entanto, acreditamos que religião é uma experiência única, extraordinária, de encontro do humano com o divino. ${ }^{39}$

Justamente em nosso livre-arbítrio, encontramos a presença de Deus, uma vez que nos é outorgada a possibilidade de fazer escolhas por intermédio do livre-arbítrio. Dessa forma, Deus está presente em nossas vidas. Para ser possível percebê-lo, porém, faz-se necessário abandonarmos nossa onipotência e narcisismo, tendo em vista que, quando nos libertamos de nossas enfermidades emocionais, despertamos para o significado da existência cristã. Assim, “[...] em vez da prova de Deus a partir do mundo, aparece a prova de Deus a partir da existência, da alma, da consciência imediata de si. Trata-se não de uma prova objetiva, mas subjetiva" 40 .

Com relação à busca humana pela divindade, Bayer escreve:

O ponto decisivo nessa questão é: para onde e para o que o ser humano está voltado. [...] Deve e pode ele olhar para fora e para longe de si - olhar

\footnotetext{
${ }^{37}$ FREUD, S. O futuro de uma ilusão (1927). Rio de Janeiro: Imago, 1996, p. 39.

${ }^{38}$ MOLTMANN, O Deus crucificado, p. 145.

${ }^{39}$ Cf. VERGOTE, Processos psicológicos, p. 22.

${ }^{40}$ MOLTMANN, Trindade e Reino de Deus, p. 28.
} 
unicamente em direção a Cristo? Ou pode ele olhar de volta para si próprio, como novo ser humano, e assim controlar o seu crescimento na fé e no amor, na nova obediência e num progresso determinado, ou seja, numa santificação como sequência da justificação? No momento em que o ser humano agraciado, novo, renascido, busca tomar o pulso de sua fé, ocorre um perigoso deslocamento, um afastamento da compreensão reformatória da fé. No momento em que os olhos se viram e olham de volta para mim mesmo e aquilo que eu faço, e assim se afastam de Deus e de sua promessa, neste momento eu estou de volta a mim mesmo e ao meu próprio juízo sobre mim. E aí inevitavelmente fico enredado, sendo jogado de volta à total incerteza do meu coração obstinado e desalentado, pois acabo ficando sozinho comigo mesmo e assim abstraio da promessa de Deus. ${ }^{41}$

Acreditamos que a resposta seja dada por Moltmann:

O amor procura um parceiro, que corresponda livremente e retribua o amor de espontânea vontade. $\mathrm{O}$ amor humilha-se por respeito à liberdade do parceiro. Aos olhos de Deus, a liberdade do homem, por ele querido e amado, é tão grande quanto o poder da paixão e da condescendência divinas. $\mathrm{O}$ amor pela liberdade constitui a base mais profunda da "autodistinção de Deus", da "bipolaridade divina", da "entrega espontânea de Deus" e da "ruptura", presente na vida e nas obras de Deus, até a consumação salvífica. ${ }^{42}$

\section{Considerações finais}

Acreditamos que esse interminável diálogo tem um longo caminho pela frente, uma vez que áreas de estudo tão distantes e aparentemente incompatíveis, como a psicanálise e a teologia, não podem rejeitar uma à outra. Não acreditamos que elas sejam necessariamente incompatíveis, mas que podem e devem contribuir entre si, de acordo com nossa pesquisa. Assim,

${ }^{41}$ BAYER, O. Viver pela fé: justificação e santificação. Tradução de Ênio R. Mueller. São Leopoldo: Sinodal, 1997, p. 41.

${ }^{42}$ MOLTMANN, Trindade e Reino de Deus, p. 43. 
concordamos com Moltmann quando ele diz que o Deus crucificado renunciou a ídolos e privilégios, demonstrando sua humanidade e sua passibilidade diante do sofrimento da Criação. Também acreditamos que internalizar a face humana de Deus requer a cura de enfermidades emocionais, tais como as neuroses, que nos impedem de atingir uma maturidade psíquica cristã. Sem essa maturidade, não somos capazes de compreender o livre-arbítrio como uma forma de nos identificarmos com a experiência religiosa completa, na qual a fé cristã é entendida e internalizada em sua forma madura.

\section{Referências}

BAYER, O. Viver pela fé: justificação e santificação. Tradução de Ênio R. Mueller. São Leopoldo: Sinodal, 1997.

BRAKEMEIER, G. O ser humano em busca de identidade: contribuições para uma antropologia teológica. São Leopoldo: Sinodal; São Paulo: Paulus, 2002.

DROGUETT, J. G. Desejo de Deus: diálogo entre a psicanálise e a fé. Petrópolis: Vozes, 2000.

FELDMEIER, R. Nem supremacia nem impotência: a origem bíblica da confissão da onipotência de Deus. Estudos Teológicos, São Leopoldo, ano 37, n. 2, p. 109-128, 1997.

FREUD, S. Além do princípio do prazer, psicologia de grupo e outros trabalhos (1920-1922). Rio de Janeiro: Imago, 1996.

. Duas histórias clínicas (o pequeno Hans e o homem dos ratos). Rio de Janeiro: Imago, 1996.

. Moral sexual "civilizada" e doença nervosa moderna (1908). "Gradiva" de Jensen e outros trabalhos (1906-1908). Rio de Janeiro: Imago, 1976.

. O futuro de uma ilusão (1927). Rio de Janeiro: Imago, 1996.

. O mal-estar na civilização (1929/1930). Rio de Janeiro: Imago, 1996. . Totem e tabu (1913[1912-13]). Rio de Janeiro: Imago, 1996.

KITAMORI, K. Teologia del dolor de dios. Salamanca: Sigueme, 1975.

MOLTMANN, J. A fonte da vida: o Espírito Santo e a teologia da vida. São Paulo: Loyola, 2002. 
. O Deus crucificado: a cruz de Cristo como base e crítica da teologia cristã. Santo André (SP): Academia Cristã, 2011.

- Teologia da esperança: estudos sobre os fundamentos e as consequências de uma escatologia cristã. São Paulo: Loyola, 2005.

. Trindade e Reino de Deus: uma contribuição para a teologia. Petrópolis: Vozes, 2000.

MORANO, C. D. Crer depois de Freud. Tradução de Eduardo Dias Gontijo. São Paulo: Loyola, 2009.

. El psicoanálisis freudiano de la religión: análise textual y comentário crítico. Madrid: Edições Paulinas, 1990.

MUELLER, E. R. "Espelho, espelho meu...": reflexões sobre os fundamentos de uma espiritualidade evangélica. Estudos Teológicos, São Leopoldo, ano 37, n. 1, p. 5-27, 1997.

RUBIO, A. G. A fé cristã em Deus Pai e a crítica freudiana da religião. Atualidades Teológicas, Rio de Janeiro, ano VII, n. 15, p. 296-322, 2003.

TILLICH, P. Teologia sistemática. Tradução de Getúlio Bertelli. São Leopoldo: Sinodal, 2002.

VERGOTE, A. Processos psicológicos - vergonha, sentimento de culpa $-e$ sentido bíblico do pecado, em particular em Romanos 7. São Paulo: Loyola, 2001.

WIEBE, D. Religião e verdade: rumo a um paradigma alternativo para o estudo da religião. São Leopoldo: Sinodal, 1998.

Recebido em: 02/10/2018

Aprovado em: 15/04/2019 